\title{
O espaço neoliberal: uma análise do discurso dos editoriais da revista veja (1985-1989)
}

\section{The neoliberal space: a discourse analysis of editorial veja magazine (1985-1989)}

João Paulo Rossatti*

Resumo: A revista Veja é, atualmente, um dos baluartes que perpetram o discurso de defesa das políticas neoliberais, já que defende o livre mercado, as liberdades econômicas e encolhimentos do Estado. Mas, para entender como esse discurso funciona hoje em nossa democracia, é preciso voltar ao começo da "Nova República" para perceber como a revista criou o que chamamos de "espaço neoliberal", utilizando suas páginas para semear ideias próprias a essa política e que, de modo geral, iriam nortear as políticas nacionais na década de 1990.

Palavras Chave: Política; revista Veja; neoliberalismo.

\begin{abstract}
Veja magazine is currently one of the stalwarts who perpetrate the discourse of defense of neoliberal policies, as it defends the free market, economic freedoms and shrinks the state. But to understand how this discourse works today in our democracy, we must return to the beginning of the "New Republic" to see how the magazine created what we call "neoliberal space", using its pages to sow own ideas to this policy and that in general, would guide national policies in the 1990s.
\end{abstract}

Keywords: Politics; Veja magazine; neoliberalism.

\footnotetext{
* Mestre em História pela Universidade Federal de Mato Grosso, Cuiabá/MT, Brasil. E-mail: jprossatti@gmail.com
}

(c) EY Direito autoral e licença de uso: Este artigo está licenciado sob uma Licença Creative Commons. Com essa licença você pode compartilhar, adaptar, para qualquer fim, desde que atribua a autoria da obra, forneça um link para a licença, e indicar se foram feitas alterações. 


\section{Introdução}

Durante a década de 1980 a revista Veja viveu grandes momentos e se consagrou como a mais importante revista semanal do país. Sua audiência média variou num número entre quatro e cinco milhões de leitores (cálculo feito pela própria revista), o que denota sua grande penetração no mercado publicístico. Ler uma revista desse porte e entender seu posicionamento, a partir dessas informações, é muito importante, pois apesar de em diversos momentos seu discurso estar alinhado às posições do governo militar ${ }^{1}$, ela defendeu a abertura política e a normalização das instituições democráticas. Para esta análise, sem desconsiderar a grande importância das reportagens em uma revista, escolhemos trabalhar apenas com o discurso perpetrado pelos editoriais do periódico, na seção chamada de "carta ao leitor", que à época eram redigidos pelo jornalista e diretor de redação José Roberto Guzzo (o jornalista ocupou este cargo de 1976 até 1991). Porém, antes de adentrarmos na análise do discurso vamos fazer uma pequena incursão pelo funcionamento do discurso jornalístico em revistas semanais e depois de feito isso tentaremos delimitar o espaço de atuação do editorial no interior do discurso jornalístico de periódicos.

Os veículos de comunicação trabalham especificamente com uma mercadoria: informação. O contrato midiático implícito entre o público consumidor e o produtor de notícias pré-estabelece algumas regras básicas que delimitam os espaços internos e externos de atuação do agente informativo. O ato de informar, nesse sentido, supõe a transmissão de um saber, ou seja, alguém que sabe algo transmite essa informação para alguém que não sabe, tirando o sujeito da situação de desconhecimento e lhe concedendo benevolamente um saber $^{2}$. Contudo, informar é um ato que faz um recorte da realidade. $\mathrm{O}$ sujeito informador seleciona os fatos em função de seu público alvo, o que denota a escolha de alguns assuntos e a exclusão de outros. A ação de selecionar o que se deve comunicar, portanto, é uma escolha e como afirma o linguista francês Patrick Charaudeau:

[...] não somente escolha de conteúdos a transmitir, não somente escolha das formas adequadas para estar de acordo com as normas do bem falar e ter clareza, mas escolha de efeitos de sentido para influenciar o outro, isto é, no fim das contas, escolha de estratégias discursivas. ${ }^{3}$

Podemos afirmar, junto com Charaudeau, que todo discurso representa uma relação (de intencionalidade) com o mundo, isto é, a informação midiática não pode ser colocada em termos de fidelidade aos fatos narrados, pois as estratégias discursivas utilizadas, na escolha dos acontecimentos, impossibilitam, por definição, a transparência e a neutralidade, de modo que podemos configurar isso como uma relação processual entre a mídia e o consumidor da seguinte maneira: existe o "mundo a descrever" no qual a 
mídia opera seu recorte e produz a informação e dessa relação decorre uma significação, ou seja, o "mundo descrito", que é consumida pela instância de recepção (o leitor) ${ }^{4}$.

Com base nesse esquema, entendemos que compreender o lugar social de quem informa é importante, pois para o público consumidor de notícias estabelece-se uma lógica automática já que quando quem informa é um órgão especializado, torna-se possível estabelecer com a informação que lhes é dada uma relação de confiança, isto é, a informação é digna de fé. O historiador Michel de Certeau explorou a circunstâncias de produção do discurso submetido às imposições do lugar de fala, inspiramo-nos em alguns de seus conceitos e aplicamos em nossa análise do discurso jornalístico. Parafraseando o autor, o jornalismo moderno estabeleceu um conjunto de regras que the permite "controlar" as operações destinadas à produção da notícia $a^{5}$. Ou seja, o jornalismo, como instituição de saber, opera sobre métodos que delimitam sua prática e sua escrita, o que lhe imputa ocupar um importante espaço de atuação no estrato social das sociedades modernas, onde estar bem informado é vital ${ }^{6}$. O texto jornalístico atende a uma demanda social por informação e a própria informação é vendida pela imprensa como um dever do métier, que o faz a serviço da cidadania e da democracia. Mas, uma análise do texto jornalístico revela que "o texto assume, ele próprio, sua relação com a instituição" , desse modo, as "leis do meio" circunscrevem a própria manufatura da unidade noticiosa. Uma notícia, para ser considerada uma "obra de valor", deve passar pelo julgamento e ser reconhecida assim pelos pares, algo que esteja fora desse círculo é tratado como fora do lugar. Assim sendo, a unidade noticiosa é produto específico de um lugar social que domina os modos de produção desse discurso ${ }^{8}$. Segundo Certeau, para saber o que um discurso diz de uma sociedade, nesse caso o discurso jornalístico, é preciso saber como ele funciona dentro dela. Fica evidente que a prática do jornalismo na sociedade contemporânea contempla o compromisso com a informação, como evidenciamos acima. No entanto, a prática jornalística se define, antes de tudo, como uma atividade comercial, ou seja, jornais, revistas, canais de televisão, entre outros meios, são empresas que estão em concorrência direta com outras que atuam no mesmo segmento, por isso o discurso jornalístico trabalha com o imperativo da captação, tentado seduzir o máximo possível de consumidores para o seu produto. A produção da unidade noticiosa é permeada por essas lógicas ${ }^{9}$. Todo discurso, portanto, parte de um interesse que funciona conforme suas condições de produção e é regulado por um espaço social que limita sua função e seu alcance.

Desse fato consumado no seio das sociedades, o contrato midiático, segundo Charaudeau, é regulado da seguinte forma:

Considerando os papéis que o jornalista deve desempenhar e, por extensão, os da instância midiática, vê-se uma vez mais a que ponto o contrato de informação está marcado 
por uma série de contradições. Em nome da credibilidade, o jornalista se coloca como simples fornecedor de informação, simples mediador entre os acontecimentos do mundo e sua encenação pública, assumindo-se como a testemunha mais objetiva possível. Na realidade, como a instância midiática é obrigada a pôr a informação em cena, esta se torna um objeto inteiramente mediado. Não raro, o jornalista se apresenta como revelador da informação oculta e, nesse sentido, assume o papel de adversário dos poderes instituídos e de aliado do público, procedendo a interrogatórios, instruindo questões, aspirando papéis de juiz e detetive. [...] Em outros momentos o jornalista se apresenta como intérprete dos acontecimentos, buscando-lhes as causas e situando-os. $\mathrm{Na}$ realidade, a instância midiática pode apenas propor algumas correlações provisórias, algumas hipóteses que, na maioria das vezes, são relativizadas ou destruídas pelos fatos posteriores. Enfim, o jornalismo pretende ser didático, aspirando ao papel de educador da opinião pública. $\mathrm{Na}$ realidade, a instância midiática pode apenas simplificar as explicações, o que não é a mesma coisa que explicar simplesmente..$^{10}$

Consequentemente, a partir dessas funções e papéis que a própria corporação se delega, a imprensa funciona como uma "máquina de construir espaço público e opinião pública" ${ }^{11}$. E ela é uma máquina de construir porque o seu discurso nunca é o correspondente exato do que aconteceu no espaço público - o que é impossível -, ao contrário, seu discurso é resultado de uma construção que seleciona e recorta o real. $\mathrm{O}$ acontecimento, na mídia, nunca é transmitido de forma pura, já que passa por critérios de seleção e por modelos narrativos que podem o tornar mais ou menos atraentes ao olhar do interlocutor. $^{12}$

Para uma delimitação mais exata de nosso objeto, esse trabalho se concentrou na análise das "cartas ao leitor". Essa seção, dentro da revista Veja - que tem a mesma função que o editorial dos jornais diários - pode ser considerado o canal por onde a opinião da revista é expressa. Um editorial tem a finalidade de comentar e distribuir apreciações sobre as principais notícias, sobre assuntos relacionados à própria revista, cultura, a política e a sociedade, enfim, um editorial não se detém sobre uma única questão. Assim, o editorial se diferencia do relato noticioso, pois demanda que o jornalista coloque em funcionamento "suas faculdades de raciocínio para analisar o porquê e o como dos seres que se acham no mundo e dos fatos que aí se produzem"13. Desse modo, o comentário no jornalismo impõe ${ }^{14}$ uma visão de mundo ao receptor.

Nessa primeira parte, portanto, tentamos delimitar, muito brevemente, o espaço do discurso jornalístico dentro de uma revista como a Veja. Agora, 
vamos adentrar no próprio texto do periódico, tendo em mente que o editorial é o canal pelo qual a imprensa expõe o seu ponto de vista ao público. Devido às características próprias que o editorial possui na imprensa, escolhemos essa seção como fonte principal para nossa análise, vamos tentar demonstrar, como, na década de 1980, a revista criou as bases discursivas para uma defesa das políticas econômicas neoliberais que tomariam contornos mais definidos na década seguinte.

\section{“O governo não é solução é problema”}

$\mathrm{O}$ ano de 1985 marcou um ponto de ruptura entre os discursos sobre a democracia. A partir desse ano, as interpretações sobre o futuro do regime tornaram-se mais abertas, logo, mais contundentes quanto ao conteúdo de suas ideias. Livres do peso do passado autoritário, o presente daquela sociedade se abriu para o novo campo de possibilidades que surgiu no horizonte e, portanto, em um período aberto ao contingente, à luta por estabelecer determinadas visões de mundo tomou grande vulto naqueles primeiros anos pós-ditadura. Falava-se que a ditadura, no limiar do século XXI, já não se justificava num país moderno como o nosso, de modo que entendemos que o fortalecimento da cultura política democrática passava pela construção de instituições estáveis que suportassem as pressões e contrapressões sociais. Esse era o objeto maior a ser alcançado.

As defesas de plena liberdade de escolha e de expressão foram os pontos que fundamentaram grande parte do discurso democrático perpetrado pela revista, esse aspecto esteve envolvido no âmbito da regulamentação da cidadania, ou seja, o voto, a liberdade de ir e vir, liberdade de escolha e associação. No entanto, em um país que passava por grave crise econômica o medo era que isso poderia dificultar a sustentação de tais instituições - Veja, por exemplo, atribui a queda de João Goulart e o mergulho no autoritarismo à perda de rumo no controle da economia -, então a primeira coisa que deveria ser feita era estabelecer uma saída para economia voltar a crescer e, assim, proteger o regime do fluxo de depauperados que surgiram devido à conjuntura do período e, consequentemente espantar de vez qualquer fantasma castrista.

Uma nova Era democrática estava sendo construída e Veja, como a maior revista semanal do país, foi importante agente no processo de disseminação de uma estrutura de ideias e linguagens políticas que foram consideráveis na conformação da opinião pública a respeito do novo regime. Por isso é importante colocar em perspectiva crítica e examinar o conteúdo dos discursos do editorial.

A revista é parte indissolúvel do processo de (in)formação do país, como ela própria assegura: "desde sua chegada às bancas brasileiras um quarto de século atrás, em setembro de 1968, Veja é parte indissolúvel do processo de formação e informação do país" ${ }^{15}$. Assim como sua audiência comprova. 
Como mostramos acima, em seu discurso ela procurou continuamente criar um espaço de influência buscando ser o porta-voz de toda uma camada social que consumia seu discurso e suas informações. Fato que é importante ter em mente, uma vez que, na metade da década de 1980, Veja tornou-se uma das mais visíveis esferas de defesa das chamadas "liberdades econômicas", a saber: livre iniciativa, liberdade de mercado, menor interferência estatal.

Depois de efetuado o processo de transição ocorreu um reajustamento nos posicionamentos políticos e por isso tornaram-se mais claras as opções e escolhas feitas pelos grupos políticos. Entre os cientistas sociais, grande mídia e a maior parte da sociedade civil havia o consenso sobre a democracia ser a melhor forma de governo, contudo, o que estava em jogo agora não era o porquê, mas sim o como obter influência sobre as ideias que norteariam o projeto de democracia no futuro. Daquele momento em diante, Veja passou a proclamar a necessidade de uma grande reforma na estrutura do Estado brasileiro, considerado pelo editorial como um grande intrometido em assuntos que não deveriam ser de sua esfera e incompetente na gestão do que era de seu encargo:

É imperioso que o novo governo, que assume o poder com um crédito de confiança popular poucas vezes igualado na história do país, mostre desde os primeiros dias que tal situação vai ter um paradeiro. Não haverá nenhuma solução digna deste nome, no próximo ou em qualquer governo, sem uma profunda reforma do Estado brasileiro, de forma a reduzir as oportunidades concretas de roubo do dinheiro público - hoje infinitas diante da imensa intromissão do governo em todos os aspectos da atividade econômica. ${ }^{16}$

Pouco menos de um mês antes da saída dos militares do Planalto, o editorial já começava a expor a faceta que orientou seus discursos até o final da década, pois o gigantismo estatal, em sua visão, era a causa da corrupção, do atraso econômico e da paralisia frente às circunstâncias socioeconômicas deploráveis em que se encontravam grandes camadas da sociedade. Seu discurso considerava indesejáveis os excessos do poder central, que no regime militar se baseava na figura forte do presidente e de alguns super-ministros que centralizavam a tomada de decisões. A solução, portanto, seria empenhar-se em desmantelar essa forma quimérica e sobrealimentada que fora assumida pelo Estado brasileiro. Se nada disso fosse feito, asseverava, corria-se o risco de iniciar uma nova república sob a sombra e os vícios da velha, isto é, para o novo governo que assumiria essa seria a oportunidade para reformar profundamente o Estado inchado herdado dos governos passados:

O passo fundamental, aí, é empenhar-se a sério num esforço de descentralização do poder acumulado na administração 
federal, suprimindo funções que podem ser suprimidas e passando outras para os Estados e os municípios. Sem isso, os chefões burocráticos da Nova República serão tão indesejáveis quanto os da Velha. ${ }^{17}$

Suprimir funções é uma clara alusão ao gigantismo estatal nocivo, que para Veja, gerava polos de corrupção e letargia. O discurso do editorial foi posto para trabalhar em favor da transformação das ideias. A revista usava as palavras como um gatilho discursivo para ativar a memória do leitor, pois por meio do discurso o fazia rememorar os aspectos indesejáveis da "Velha República" que para o periódico e, consequentemente, para seus leitores, não deveriam se repetir nesse momento novo e singular da história republicana. O editorial começou a deixar visíveis quais ideias e linguagens recorreu para compor sua visão de mundo, já que começou a expor mais abertamente suas perspectivas. Se antes, devido a circunstâncias particulares do regime, os editoriais apontavam caminhos possíveis para um país governado por um governo autoritário, na era democrática, escudada pela liberdade de expressão, a revista acenou com as soluções, ou seja, para um "país que já perdeu preciosos anos com a arrogância e a incompetência dos autocratas e com o atendimento de interesses subalternos" 18 , o recurso seria afastar o Estado o máximo possível deixando a livre iniciativa privada tomar as decisões. ${ }^{19}$ Veja criou uma atmosfera discursiva que visou criar junto as seus leitores uma visão comum que tentava coibir a interferência estatal na vida econômica relegando-a ao mínimo possível (deixando o Estado atuar somente nos assuntos básicos: saúde, segurança, educação), isso implicou no uso de linguagens e expressões em direta associação com as ideias do capitalismo praticado à época, escorado na ideia de uma democracia de livre mercado. Seus dizeres estão impregnados por uma cultura política que vê no gigantismo do Estado um dos principais problemas políticos de uma sociedade, pois reprime o cidadão comum e o espreme entre opções que não formula, e soluções das quais não partilha, conforme expressão de Raymundo Faoro. A linguagem e a carga de sentido que ela (a revista) enseja criar estava impregnada por sua posição social, de modo que o lugar de produção do discurso é também o espaço de produção de sentido, como afirma Orlandi: "consequentemente, podemos dizer que o sentido não existe em si mas é determinado pelas posições ideológicas colocadas em jogo no processo sócio-histórico em que as palavras são produzidas". ${ }^{20}$ Por isso a linguagem da revista apontava para os riscos do retrocesso político quando o Estado avançava sobre a iniciativa privada em vez de recuar: "O perigo crucial, na verdade, está dentro do próprio governo, quando as autoridades econômicas, seja lá quais forem suas intenções, passam a agir contra o espirito da reforma que fizeram". ${ }^{21}$ As reformas a que Guzzo se refere são as do Plano Cruzado, que previam uma diminuição das atribuições do Estado brasileiro, mas não foram levadas a cabo pela equipe administrativa, que continuou, ao contrário, 
a aumentar sua participação nos setores industriais e a regulamentar vários outros setores da economia. A revista expõe claramente seu ponto de vista com relação a isso em editorial de abril de 1986:

O mais danoso, neste intervencionismo autoritário e arrogante, não é propriamente a pretensão de determinar onde os cidadãos têm de aplicar seu dinheiro, ou qual porcentagem desse seu dinheiro eles têm de colocar nisso ou naquilo, ou quanto têm de investir em papeis do governo. [...] Quando as autoridades econômicas voltam a querer que o Estado regule tudo, em vez de ocupar-se apenas das funções que lhe são inerentes, a vitima principal é a grande esperança que o país começou a viver a partir de 28 de fevereiro. ${ }^{22}$

Estancar as feridas causadas por uma inflação na casa dos três dígitos ao ano, com picos de até $16,2 \%$ ao mês, forçou o governo a lançar um audacioso plano de ataque ao crescimento descontrolado de preços. No final de fevereiro de 1986, quando o Plano Cruzado foi lançado, o país assistiu a um enorme esforço de escala nacional na tentativa de recuperar as instituições econômicas falidas - o "milagre econômico" já havia ficado para trás, tornara-se apenas uma lembrança distante, o que ficou visível dele foi a "herança maldita" do regime militar - que sobreviveram artificialmente sustentadas por um Estado enorme e fechado frente às mudanças da própria sociedade (vale lembrar aqui das famosas reservas de mercado que proibiam a importação de veículos e computadores, por exemplo).

Quando o Plano Cruzado deixou o campo das ideias para se tornar realidade, as reformas por ele propostas para drenar a sangria das finanças públicas, apoiada no receituário liberal em voga à época, foram muito bem recebidas pelo editorial, pois, apontavam para algumas soluções já prescritas pela própria revista Veja, e apresentava a esperança de, enfim, ingressar em um período de paz, tranquilidade e prosperidade. Tudo o que a democracia brasileira precisava para frutificar:

[...] Tanto VEJA quanto a Editora Abril manifestaram seu claro apoio à reforma econômica deste o primeiro momento - não apenas do ponto de vista editorial, mas também em nossa conduta como empresa. $\mathrm{O}$ aumento de preço de capa, transformado pela inflação galopante numa rotina indispensável, que estava previsto para a primeira edição de março, foi cancelado já na sexta-feira, dia 28 de fevereiro. [...] Quanto à reforma, é importante notar que começa agora um período de vital importância para o nosso futuro. Nenhum de nós, no fundo, sabe realmente 
o que significa viver num país sem inflação ou de inflação baixa. A primeira grande mudança, portanto, terá de ser feita na mentalidade de cada um: precisamos aprender que não é possível ganhar mexendo apenas com papéis, que não se pode ter expectativas de salários sempre crescente sem a correspondente produtividade, que poupar é um processo lento, destinado a gerar efeitos alongo prazo e não a dobrar ou triplicar economias de um dia para o outro. [...] O entusiasmo com que a reforma foi recebida em todo o país é um extraordinário indicador de como a população brasileira estava ávida por mudanças e uma confirmação de que o momento escolhido para empreendê-las não poderia ter sido melhor. Do ponto de vista político, social e econômico o país, como um todo, só ganhou. O governo está mais forte e unido, a ameaça de greves ruinosas perdeu muito de sua força e o espectro do caos gerado pela hiperinflação foi afastado. Restam, agora, os problemas básicos de conduta. De um lado, será indispensável que as pessoas aceitem as novas regras do jogo sem tentar ganhar alguma vantagem adicional às custas dos outros. Do lado do governo, teremos de exigir que resista às inevitáveis pressões para emitir dinheiro, fazer concessões ou criar exceções - e que controle os seus próprios gastos. Junto com a grande maioria do país, VEJA está na torcida. ${ }^{23}$

Neste editorial a tomada de posição é evidente, assim como também é evidente o projeto de democracia que ela traz consigo. Reverbera no discurso os ideais da democracia de livre-mercado em que o Estado é mínimo. Portanto, não surpreende que quando este caminho não foi seguido pelo governo no pacote econômico o editorial atrelou o peso do passado à inépcia governamental em atuar a favor da liberalização da economia. Diante do exposto, Veja afirmou: “eliminaram-se nos últimos anos todos os chamados 'entulhos autoritários', menos um, e precisamente o principal: o gigantismo do Estado". ${ }^{24}$ A revista inspirava-se nos modelos econômicos praticados pela Inglaterra e Estados Unidos que, no período, segundo a revista, demonstravam sua eficiência, sobretudo o modelo inglês, que não à toa foi saldado por Veja como "o" caminho a ser trilhado rumo a tão sonhada modernidade brasileira:

A desestatização da economia inglesa tem feito progressos notáveis, distinguindo-se de tantas outras tentativas fracassadas na área, justamente porque ali existe uma vontade genuína de diminuir a presença do Estado no sistema produtivo. Quando ela existe, acham-se com relativa facilidade os meios de devolver à iniciativa privada atividades que o governo tomou a si. Não existindo, o que 
se acha são desculpas para deixar tudo do jeito que está. O exemplo britânico é particularmente oportuno neste momento, quando se discute dentro do governo brasileiro de que maneira os contribuintes pagarão, daqui por diante, os monstruosos prejuízos da Siderbrás, a grande estatal do aço. $^{25}$

Segundo o editorial, a menos que o Estado brasileiro estivesse disposto a diminuir seu próprio tamanho, o caos teria prosseguimento. A partir desta perspectiva, o que fica claro é que o Estado não pode ser agente produtor ${ }^{26}$, tal qual a iniciativa privada, antes de tudo ele deve apenas ser um regulador dos interesses privados, o lugar que dá estabilidade e possibilita o crescimento, e não o contrário:

O Estado, no Brasil, pretende fabricar aço, levantar usinas nucleares, construir aviões e, em geral, realizar uma multidão de tarefas para as quais não tem nem aptidão nem dinheiro. Não consegue, porém, cumprir com um mínimo de decência nem ao menos uma entre aquelas poucas incumbências básicas que seria a sua obrigação natural desemprenhar. [...] Pode-se dizer que existe uma simetria entre o crescimento do Estado e a piora das condições de vida dos brasileiros mais necessitados. Quanto maior fica o governo, e quanto mais ele se mete a querer fazer tudo, desde dividir terras até regular o mercado de computadores, menos sobra para a população - e é do entendimento dessa noção que depende qualquer possibilidade de melhoria efetiva na vida do país. O governo não é solução, é problema. Para que as pessoas deixem de ser transportadas como animais, de perder o valor de seus salários com a inflação, de ficar sem empregos na recessão e de sofrer a infinidade de problemas que sofrem, é indispensável uma reforma radical na máquina que engole a maioria dos recursos nacionais e é o agente criador da maioria dos problemas. O Estado brasileiro, no fundo, não serve a nenhum outro propósito que não seja o de servir a si próprio-algo que se manifesta não apenas no plano federal e no Poder Executivo, mas também a níveis estaduais, nos municipios e no Legislativo. Essa situação, que persiste e se agrava de governo em governo, bloqueia não apenas as perspectivas de bem-estar dos brasileiros. Ela bloqueia, na verdade, a viabilidade do Brasil como um país moderno. ${ }^{27}$

Após a longa transição que recuperou para a sociedade civil alguns de seus direitos fundamentais, conforme mostramos nos capítulos anteriores, o 
espaço de maior liberdade possibilitou a revista Veja iniciar abertamente sua escalada discursiva. Chamamos de "escalada" porque conforme a democracia foi se assentando e o regime dos militares sendo substituído, a tomada de posição ficou mais evidente e também mais recorrente. Se em 1980, o editor em poucas linhas descrevia as suas ideias: "fora dos regimes democráticos, ou seja, aqueles regimes que prezam acima de tudo os direitos individuais, $a$ liberdade de empreender e a possibilidade de cada um conduzir sua existência da forma que julgar melhor". ${ }^{28}$ Ao longo do tempo, a essência do discurso não muda, já se apresentava aquelas ideias que o nortearia. Contudo, a passagem dos anos e o agravamento da crise ajudaram a aumentar o tom incisivo das ideias que circulavam pelas páginas da revista e, consequentemente, pautavam os dizeres do periódico e de seu editorial. A disposição para o consenso deu lugar a uma luta aberta contra o que a revista chamava de "ditadura fiscal" 29 , que sub-repticiamente surrupiava o já corroído salário da maior parte dos trabalhadores brasileiros. Tudo isso para sustentar uma máquina ineficiente e corrupta, segundo a revista.

Se entre a intelectualidade que escreveu sobre a democracia brasileira nos anos 1980 havia o consenso de que a soberania deveria ser devolvida ao cidadão, e esse cidadão era representado principalmente pela figura do trabalhador (urbano e do campo), que escolheria através do voto a melhor forma de regular a mediação entre o público e o privado, na visão do editorial, o que deveria regular, a partir de então - além do poder do povo -, esses espaços de interação do tecido social era a livre iniciativa, e, portanto, o ponto principal seria esse: "uma das discussões centrais da vida nacional [...] está precisamente na necessidade de se remarcar, para trás, a presença do Estado na vida alheia" ${ }^{30}$ Para a revista o Estado, além de ter se mostrado incapaz de produzir riqueza através da indústria, foi também incapaz de transferir riqueza, de realizar uma melhora nas condições de vida do povo:

Desde já, porém, que fique claro que a opinião pública não pode ser engabelada com o colossal embuste segundo o qual o aumento nos percentuais seria uma medida de "redistribuição de renda", na qual todos pagam os benefícios dos mais necessitados. Atribuir a órgãos do Estado a tarefa de redistribuir renda já é uma ideia discutivel. Mas atribuíla justamente ao órgão estatal que comprovou, de forma exaustiva e cabal, ser o mais incompetente de todos para mexer com o dinheiro público é insultar a inteligência dos brasileiros. ${ }^{31}$

Em 1987, quando a nova Constituição começou a ser discutida, para Veja, viu-se ali a chance e os meios legais de se marcar "para trás" a presença do Estado por meio de um texto que, através de leis sempre sensatas e justas, 
preparassem o terreno para a liberdade..$^{32}$ Decorrente desse seu posicionamento, ficou evidente a sua decepção quando teve início as discussões acerca das emendas constitucionais que, segundo a revista, iam à contra mão da modernidade:

Enquanto a Europa dispara em direção ao século XXI, no Brasil as elites no poder continuam acreditando, ou fingem acreditar, que é possível resolver questões econômicas redigindo-se um artigo na Constituição - como ocorreu, ainda na semana passada, com a decisão de se limitar a cobrança de juros reais em $12 \%$ ao ano. Em todas as ocasiões nas quais ocorreu o choque entre o moderno e o arcaico, na ordem econômica, a Constituinte optou decididamente por andar para trás. Os países europeus querem abrir-se mutuamente para permitir que o progresso possa ser absorvido pelo outro, constituindo-se, assim, uma prosperidade comum. Nossos constituintes querem deixar o Brasil fora do mundo e o mundo fora do Brasil. ${ }^{33}$

Em todo o capítulo, da Ordem Econômica, de um modo geral, o documento é retrogrado, preferindo prestar vassalagem a ideologia e preconceitos, em vez de abrir caminho para uma organização mais moderna da economia brasileira. O desenvolvimento e o progresso do país terão de ser buscados em outras esferas - não será na Constituição que se vai achar um instrumento eficiente para promovê$\operatorname{los}^{34}$

A receita, portanto, era simples: para tornar o país mais próspero era preciso apenas uma coisa, enxotar o governo das áreas onde este se intrometia indevidamente. Era, destarte, imprescindível andar de mãos dadas com o moderno, e esse moderno significava a libertação do mercado das correntes de um governo arcaico e inapto:

Num momento da História em que as sociedades mais comprometidas com o progresso e o avanço social tomam decididamente o caminho da liberdade econômica e da internacionalização, a máquina governamental e grande parte das elites politicas e intelectuais do Brasil insistem em conduzir o país no sentido contrário, à força de ideias mortas e retórica demagógica. ${ }^{35}$

O discurso mantém o tom peremptório em uma série de editoriais no ano de 1987, propondo limites contundentes que deveriam existir entre a 
esfera pública e a privada: "A caminhada para frente, que pode ir tornando o Brasil mais parecido com sociedades mais avançadas do mundo de hoje, só se dará numa sociedade onde a economia seja genuinamente aberta e onde haja incentivo real à criação de riquezas" 36 e prossegue "o governo e os constituintes não podem achar que seja possível se viver num mundo no qual se exporta mais, recebem-se investimentos e, ao mesmo tempo massacra-se a atividade privada". ${ }^{37}$ Constantemente associava o caminho da modernidade como uma estrada diametralmente oposta àquela que o país seguia. A visada de significado que se constrói, conforme o exposto é a da continuidade do país "real" e do "imaginário", metáfora muito utilizada na época para exprimir o desnível entre a política praticada no Planalto e a situação cotidiana da sociedade civil. Não é por acaso que se escolhem palavras fortes para descrever a atuação do governo nesse tipo de situação: "a xenofobia exibida no caso dos combustíveis é ao mesmo tempo intelectualmente raquítica e politicamente demonstrativa de um sentimento antiprivatista, retrógrado e cartorial. Em nenhum momento decide-se levando em conta o progresso do país". ${ }^{38}$

A revista se vale da estratégia de convocação do leitor, por meio de um método discursivo bem estabelecido, ao associar presença do Estado com algo retrógrado e anti-moderno, ou seja, com isso o Brasil estaria condenado ao atraso eterno provocado por governantes que foram eleitos para fazer justamente o contrário. Isto é, a modernidade ainda não havia sido alcançada porque onde o governo brasileiro se intrometeu onde não deveria. Por onde passou e onde avançou, apenas causou desequilíbrios e gerou problemas para o povo que fora mantido à distância das principais decisões:

Toda vez que se faz uma tentativa qualquer de melhorar alguma coisa na economia brasileira através da soma de esforços dos diversos setores da sociedade, pode-se apostar, de olhos fechados, no resultado que se acaba obtendo: o setor privado, bem o ou mal, desemprenha o seu papel, o setor público nunca desempenha o seu. Ou melhor, faz sempre, e exclusivamente, aquela parte do papel que the agrada - a de arrecadar mais - e ignora por completo aquela que lhe repugna - a de gastar menos. Foi assim, mais uma vez, na semana passada, quando o Executivo, agora com a cooperação de um Congresso investido de novas prerrogativas constitucionais em matéria fiscal, disparou um pacote de impostos que penaliza os negócios privados e engorda os negócios públicos. ${ }^{39}$

Confirmava-se a convicção de que o Estado havia esgotado seu papel como agente primordial do desenvolvimento, por isso ele precisava ser dragado para fora do mercado, deixando este último se autogerir, pois "bem 
ou mal ele desemprenha seu papel". Em linhas gerais, o governo seria o agente do caos, atrofiado por uma incapacidade mórbida, comezinha e preso pelos pés ao mais pesado concreto, pois por mais que o país estivesse livre dos arbítrios autoritários no que tange a cidadania, a economia ainda estava sujeita aos princípios que nortearam a construção do Estado brasileiro no pós30; a industrialização nacional forjada por programas de crescimento estatal e marcada por imposições autoritárias durante a maior parte do século XX. O capitalismo, livre da fúria legiferante poderia prosperar, assim como o que acontecia no caso do mercado de ações, a "casa" do capitalismo moderno:

\begin{abstract}
Num quadro mais amplo, porém, o principal beneficiário da vitalidade da bolsa de valores é o país como um todo. De um lado, a animação do mercado de ações leva a um segundo fortalecimento da livre iniciativa, através da democratização do capital das empresas - a grande resposta que o capitalismo tem a oferecer às tendências estatizantes e aos impulsos de socialização. De outro, assegura o fluxo de recursos de que as empresas necessitam para investir em seu crescimento ou modernização - o que lhes permite aumentar a produção, exportar, gerar empregos, pagar impostos. ${ }^{40}$
\end{abstract}

Para a revista apenas o desmonte de um pedaço considerável da máquina federal poderia dar forma ao projeto de Brasil que se imaginava construir. $\mathrm{O}$ empresariado nacional, para se desenvolver e fazer a economia voltar a crescer, para gerar empregos e renda, precisava estar livre da bola de ferro que estava presa em seu tornozelo. O empresariado, neste caso, representa o "nós" do discurso, pois, sendo a Editora Abril uma empresa, agradava a ela também ter um clima de maior liberdade econômica (pelo menos no discurso), com menor cerceamento da "ditadura fiscal", em consequência disso, o lugar do discurso deixa transparecer o desejo de boa parte da classe que comandava a economia no país, pois: "a economia brasileira, pelo menos a que está nas mãos da iniciativa privada, é poderosa, diversificada". ${ }^{41}$

A problemática da intromissão estatal no mercado tomou vulto ainda maior durante o ano de 1989, quando foram realizadas as eleições diretas para presidente, a primeira desde o fim do regime castrense. Enquanto, por um lado, se reforçava de forma ainda mais o contundente os benefícios do regime democrático, tal como podemos ver no seguinte trecho: "O país vive hoje um de seus melhores momentos políticos: o da democracia plena, do livre debate acerca das alternativas para o futuro e da disputa do voto popular"42. Por outro lado, escancaram-se as disputas pelos remos que iriam guiar o barco nos próximos anos. Nessa eleição, talvez a mais concorrida e a mais representativa na história do país, 22 candidatos disputaram o poder - e em 
um dos piores momentos da crise econômica naquela década, que acumulava uma inflação de cerca de $35.000 .000 \%$ no último decênio. Ao fim chegaram ao segundo turno o candidato, pelo PRN, Fernando Collor de Mello e, pelo PT, Luiz Inácio "Lula" da Silva.

Representando polos contrários do espectro ideológico político, o primeiro estava alinhado aos desejos da classe média e empresarial do país, o segundo possuía um discurso mais próximo aos preceitos socialistas e, portanto, reforçava a intenção de fortalecer a economia por meio do Estado. Ou seja, um era privatista e o outro estatista e, como mostramos até aqui, o editorial apresentou durante toda aquela década um discurso que esteve fortemente marcado por uma defesa da liberalização política e econômica. No entanto, o que isso representava na prática? O país, àquela altura, não precisava de governos centralizados, que apenas serviram para criar "anéis burocráticos", para usar uma expressão de Fernando H. Cardoso, que obstruíam o funcionamento positivo da livre iniciativa, ao contrário, a sociedade brasileira precisava de um governo comprometido em desmantelar a máquina burocrática e liberar plenamente a livre iniciativa, de acordo com o discurso da revista. Desse modo, aquilo que o editorial defendeu por uma década foi personificado nas propostas de Fenando Collor, "o caçador de marajás", já que este prometeu em campanha uma intensa batalha contra o privatismo estatal. ${ }^{43}$ Durante a campanha a revista deixou evidente qual era a sua visão sobre o caminho certo para o Brasil:

Tanto Fernando Collor de Mello como Luís Inácio Lula da Silva prometem derrubar o muro das vergonhas que separa a maioria dos brasileiros das condições mínimas de levar uma vida decente. A questão é como acabar com esse muro - e os candidatos apresentam respostas bem diferentes, como se pode constatar na reportagem de capa desta edição. VEJA considera que não será com estatização, com cerceamento à livre iniciativa, com o incremento de conflitos entre capital e trabalho, com restrições aos investimentos, com o isolamento do mundo desenvolvido e com o nivelamento por baixo que o país irá melhorar. A revista defende desde a sua fundação, e a reafirma nesta véspera de eleição, que o caminho para melhorar as condições de vida dos brasileiros é o da liberdade política e econômica, com o Estado se limitando a atuar na área de infra-estrutura econômica e social e servindo de catalisador e redistribuidor dos frutos do desenvolvimento. É com base na defesa da liberdade política e econômica que VEJA cobrará do próximo presidente resultados concretos das promessas feitas por ele durante a sua campanha. Principalmente da promessa de melhoras decisivamente as condições sociais do país. ${ }^{44}$ 
Este editorial, um dos últimos publicados naquela década, revela a proposta de futuro e, principalmente, a concepção democrática a qual se filia a revista, que podemos elencar aqui em três posições principais: $1^{\circ}$ liberdade individual sem constrangimentos (de expressão, associação); $2^{\circ}$ livre iniciativa econômica; $3^{\circ}$ Estado mínimo. Sabemos que a vitória de Fernando Collor no final de 1989 marcou o primeiro passo da entrada do país na Era neoliberal, com a abertura da economia aos mercados estrangeiros, desmanche da estrutura estatal com início do processo de privatização de grandes empresas públicas como a Telebrás e a Vale do Rio do Doce (já no governo FHC). Isto é, o receituário econômico de inspiração inglesa, admirado pela revista que era guiado pelo espirito da privatização do setor público foi o manche que guiou a construção da democracia de livre mercado implanta no Brasil ao longo dos anos 1990, tão defendida por Veja ao longo da década de 1980. A revista ajudou a pôr em circulação linguagens e ideias advindas dessa forma de gerir e conceber a política, mostrando assim estar muito próxima dos ideais políticos que imperavam no mundo Ocidental naquele período, do que ligada aos debates e formas de pensar a construção da democracia pelos intelectuais brasileiros.

A revista, ao colocar em circulação esse tipo de ideias, além de tornar notória a tradição política a que estava ligada, mostra a forma como participou do processo de conformação da opinião pública em torno do conceito de democracia ao longo dos anos 1980. Em um momento de intensa disputa entre as diferentes famílias políticas, Veja escolheu aquela que definiria a sua identidade e que vai nortear seu discurso nas décadas seguintes. Grosso modo, construiu sua visão de mundo apoiada nos preceitos da cultura política da democracia de livre mercado tornando-se, assim, um espaço neoliberal.

\section{Notas}

1 Como mostraremos mais a frente.

2 CHARAUDEAU, Patrick. Discurso das mídias. São Paulo: Contexto, 2013. p. 33.

3 Idem. p. 39 (grifos do autor)

4 CHARAUDEAU, P. Op. Cit. p. 42.

5 CERTEAU, Michel. A escrita da história. Rio de Janeiro: Forense, 2013. p. 47.

6 Como pode ser visto em trecho do primeiro editorial da revista no ano de 1968: "O Brasil não pode mais ser o velho arquipélago separado pela distância, o espaço geográfico, a ignorância, os preconceitos e os regionalismos: precisa de informação rápida e objetiva a fim de escolher rumos novos. Precisa saber o que está acontecendo nas fronteiras da ciência, da tecnologia e da arte no mundo inteiro. Precisa acompanhar o extraordinário desenvolvimento dos negócios, da educação, do esporte e da religião. Precisa, enfim, estar bem informado.” VEJA n. 01 11/09/1968 (grifos nossos)

7 Idem. p. 55.

8 Idem. p. 57. 
9 CERTEAU, M. Op. Cit. p. 58-59.

10 CHARAUDEAU, P. Op. Cit. p. 77-78.

11 Idem. p. 114.

12 Idem. p. 151.

13 CHARAUDEAU, P. Op. Cit.. p. 175.

14 No sentido de estabelecer uma forma de ver o mundo e não no sentido de obrigar a ver de tal forma.

15 Introdução do suplemento: Veja 25 anos: Reflexões para o futuro. São Paulo: Editora Abril, 1993. p. 03.

16 Veja, $n^{\circ} 858,13 / 02 / 1985$. p. 19.

17 Veja, $n^{\circ} 862,13 / 03 / 1985$. p. 27.

18 Veja, no 869 01/05/1985. p. 19.

19 Sobre isso ver mais informações nos seguintes editoriais: Veja, $n^{\circ} 873,29 / 05 / 1985$. $p$.

15; Veja, no 882, 31/07/1985. p. 19; Veja, no 913, 05/03/1986. p. 19.

20 ORLANDI, Eni Puccinelli. Análise de discurso: princípios e procedimento. CampinasSP: Pontes, 2000. p. 42.

21 Veja, $n^{\circ}$ 920, 23/04/1986. p. 19.

22 A "grande esperança" a que se refere Guzzo é o Plano Cruzado, que começou a funcionar em de fevereiro de 1986. Idem, Ibidem.

23 Editorial escrito por Victor Civita proprietário e fundador da Editora Abril. In: Veja, $\mathrm{n}^{\mathrm{o}}$ $914,12 / 03 / 1986$. p. 19. (grifos nossos)

24 Veja, $n^{\circ} 1051,26 / 10 / 1988$. p. 43.

25 Veja, $n^{\circ} 946,22 / 10 / 1986$. p. 35.

26 O Estado não deve nem se "intrometer" na cultura: "Num país infestado por um sem-número de institutos, fundações, departamentos, secretarias e até um Ministério da Cultura, todos criados e mantidos pelo Estado com a justificativa de serem indispensáveis à civilização brasileira [...].” In: Veja, no 957, 07/01/1987. p. 19. (grifos nossos)

27 Veja, ${ }^{\circ} 983,08 / 07 / 1987$. p. 17. (grifos nossos)

28 Veja, $n^{\circ} 625,27 / 08 / 1980$. p. 15. (grifos nossos)

29 Veja, $n^{\circ} 717$, 02/06/1982. p. 19.

30 Veja, $n^{\circ} 927,11 / 06 / 1986$. p. 35.

31 Veja, $n^{\circ} 673,29 / 07 / 1981 . p .19$. (grifos nossos)

32 Veja, no 961, 04/02/1987. p. 19.

33 Veja, $n^{\circ} 1028,18 / 05 / 1988$. p. 17. (grifos nossos)

34 Veja, no 1044, 07/09/1988. p. 31

35 Veja, no 996, 07/10/1987. p. 19

36 Veja, no 997, 14/10/1987. p. 19 
37 Veja, $n^{\circ} 1002,18 / 11 / 1987$. p. 19

38 Veja. Idem. Ibidem.

39 Veja, no 1058, 14/12/1988. p. 45.

40 Veja, no 853, 09/01/1985. p. 19.

41 Veja, $n^{\circ} 1080,24 / 05 / 1989$. p. 39.

42 Veja, $n^{\circ} 1100,11 / 10 / 1989$. p. 43

43 Veja, no 1109, 13/12/1989.

44 Idem. p. 43. (grifos nossos)

Recebido em 06/08/2017

Aprovado em 02/12/2017 